\title{
Animal viral diseases and global change: bluetongue and West Nile fever as paradigms
}

\author{
Miguel Á. Jiménez-Clavero* \\ Centro de Investigación en Sanidad Animal, Instituto Nacional de Investigación y Tecnología Agraria y Alimentaria, Valdeolmos, Spain
}

\section{Edited by:}

Rubén Bueno-Mari, University of

Valencia, Spain

Reviewed by:

Tamas Bakonyi, Szent Istvan

University, Hungary

Michael Eschbaumer,

Friedrich-Loeffler-Institut, Germany

Giovanni Savini, Istituto G. Caporale

Teramo, Italy

${ }^{*}$ Correspondence:

Miguel Á. Jiménez-Clavero, Centro de Investigación en Sanidad Animal,

Instituto Nacional de Investigación y

Tecnología Agraria y Alimentaria,

Ctra Algete-El Casar s/n, 28130

Valdeolmos, Spain.

e-mail:majimenez@inia.es
Environmental changes have an undoubted influence on the appearance, distribution, and evolution of infectious diseases, and notably on those transmitted by vectors. Global change refers to environmental changes arising from human activities affecting the fundamental mechanisms operating in the biosphere. This paper discusses the changes observed in recent times with regard to some important arboviral (arthropod-borne viral) diseases of animals, and the role global change could have played in these variations. Two of the most important arboviral diseases of animals, bluetongue (BT) and West Nile fever/encephalitis (WNF), have been selected as models. In both cases, in the last 15 years an important leap forward has been observed, which has lead to considering them emerging diseases in different parts of the world. BT, affecting domestic ruminants, has recently afflicted livestock in Europe in an unprecedented epizootic, causing enormous economic losses. WNF affects wildlife (birds), domestic animals (equines), and humans, thus, beyond the economic consequences of its occurrence, as a zoonotic disease, it poses an important public health threat. West Nile virus (WNV) has expanded in the last 12 years worldwide, and particularly in the Americas, where it first occurred in 1999, extending throughout the Americas relentlessly since then, causing a severe epidemic of disastrous consequences for public health, wildlife, and livestock. In Europe, WNV is known long time ago, but it is since the last years of the twentieth century that its incidence has risen substantially. Circumstances such as global warming, changes in land use and water management, increase in travel, trade of animals, and others, can have an important influence in the observed changes in both diseases. The following question is raised: What is the contribution of global changes to the current increase of these diseases in the world?

Keywords: global change, climate change, emerging diseases, bluetongue, West Nile virus

\section{INTRODUCTION}

Infectious disease can be viewed as a play involving at least two characters: the pathogen and the host. While both roles can be represented by a great variety of performers, pathogens exhibit by far the highest variety and complexity. This review is about viral infections in animals. It aims first to give an idea of the enormous complexity and diversity of the existing infectious agents, emphasizing their extraordinary capacity for change and adaptation, which eventually leads to the emergence of new infectious diseases. Secondly, it focuses on the influence of the environment in this process, and on how environmental (including climate) changes occurring in recent times, have precise effects on the emergence and evolution of infectious diseases, some of which will be illustrated with specific examples. Finally, it describes the recent and dramatic expansion of two of the most important emerging animal viral diseases at present, bluetongue (BT) and West Nile fever/encephalitis (WNF), dealing with their relationship to climate and other environmental changes, particularly those linked to human activities, collectively known as "global change," and that can be at least in part seen a consequence of the "globalization" phenomenon.

\section{EMERGING VIRAL DISEASES OF ANIMALS COMPLEXITY AND DIVERSITY OF ANIMAL VIRUSES}

To illustrate the enormous complexity of animal viruses, consider the following example: take any animal species, e.g., bovine. There are five known species of herpesviruses that could infect bovines specifically. Similarly, there are nine different known equine herpesviruses, eight human herpesviruses, and so on and so forth (Pellet and Roizman, 2007). Bearing in mind that there are approximately 5,400 different species of mammals (Wilson and Reeder, 2005 ) and that most of them have yielded at least one, most frequently several distinct herpesviruses on examination, the number of existing mammalian herpesvirus species would be huge, probably in the range of thousands. But there are also herpesviruses specific for birds, for reptiles, for amphibians, etc., so the above number would be increased consequently with the number of other vertebrate species (for the moment viruses of invertebrates, a world largely to be discovered, will not be considered). Likewise, let's bear in mind that there are other taxonomic families of viruses besides the Herpesviridae family, like the Poxviridae (e.g., smallpox and myxomatosis), Flaviviridae (e.g., yellow fever and dengue), Orthomyxoviridae (e.g., influenza), Picornaviridae 
(e.g., foot-and-mouth disease, polio, and hepatitis A), Reoviridae (e.g., BT and African horse sickness), etc., and for each family of viruses one can reason about in the same way. In light of this example, a first conclusion is that we only know a fraction of the viral pathogens that actually exist. To these, we must add the non-pathogenic viruses that circulate silently, which obviously are less known, and which probably exist in far greater numbers and variety than their pathogenic counterparts. The complexity of viruses of plants, bacteria, fungi, and parasites is not lower than that of animal viruses. This gives a rough idea of the real complexity of the virus world in which only a small part is known.

\section{THE GENESIS OF INFECTIOUS DISEASES}

Despite the distress and alarm that the emergence of a new infectious disease causes, the fact is that organisms change over time in adaptive processes that determine their evolution, and this implies the emergence of new infectious diseases and the disappearance or change of the existing ones. These processes are therefore normal and expected to occur with some frequency, as a result of the high generation rates and enormous capacity for mutation and adaptation exhibited by microorganisms in general, and viruses in particular.

The term emerging infectious diseases applies to those diseases in which any of the following situations is applicable: (1) a known infection spreading to a new geographic area or population, (2) a new infection that occurs as a result of evolution or change of an existing pathogen, and (3) a previously unknown disease or pathogen that is first diagnosed (Brown, 2004; OIE, 2011). Factors determining the emergence of an infectious disease are largely unknown, although they are related to the adaptation of infectious agents to new species (Lederberg, 1997) and/or to the concomitant appearance of changes in the environment that offer new opportunities for pathogens to thrive (Smolinski et al., 2003). With regard to adaptation to new species, first it is worth reminding that every virus has its own "host range," that is, the variety of species susceptible to be infected by a particular virus. There are, on one hand, viruses with a broad range of hosts, for example, West Nile virus (WNV), that is capable of infecting hundreds of species of birds, as well as many species of mammals, reptiles, and amphibians (McLean et al., 2002), and, on the other hand, viruses with a narrower range of hosts such as, for instance, classical swine fever virus, which only infects suidae (pigs and wild boar; OIE, 2008), or the aforementioned herpesviruses, each of which usually infect specifically one or a few related species (Pellet and Roizman, 2007).

Two cases can be distinguished with regard to pathogen adaptation to new host species: in the first, the pathogen completes its cycle and survives normally in a given species which acts as reservoir host, but occasionally infects other(s), causing disease in these "incidental hosts." This occurs in a number of zoonoses. A good example is given by highly pathogenic avian influenza virus subtype $\mathrm{H} 5 \mathrm{~N} 1$ of Asian origin (H5N1 HPAIV), now present on three continents. Different wild birds act as reservoir hosts for this virus, which affects severely different species of domestic poultry, causing enormous losses to the poultry industry (Alexander, 2000). However, besides birds, it occasionally affects some species of mammals, including humans (causing a zoonosis), cats, and mustelids like ferrets and martens, in which it is extremely pathogenic. Nevertheless, transmission of H5N1 HPAIV between individuals in mammal species is not effective at all (Imai and Kawaoka, 2012), a fact that luckily prevents by now a possible pandemic of disastrous consequences for humankind. In the second case, the adaptation to new species is more "genuine" in the sense that the pathogen has indeed crossed the "species barrier," that is, has established a complete cycle of transmission in a new species. It can be assumed that all viruses currently known went through a process like this in their past evolution to adapt to the species which are their current natural hosts. Influenza viruses themselves were adapted to their avian hosts in remote times. Some of them gave rise, through analogous adaptation processes, to the current swine, equine, and human influenza viruses, which are able to complete an infectious cycle in these species, independently of birds (Suarez, 2000). Among the viruses that have undergone a process of adaptation to a new species, it is worth reminding the case of swine vesicular disease virus, which causes an economically important disease in pigs (Escribano-Romero et al., 2000). This virus is closely related genetically to Coxsackie virus B5, a human enterovirus, and current evidence suggests that it arose as a result of a relatively recent adaptation from human to swine (Jimenez-Clavero et al., 2005a), providing a good example that adaptations and crossing the species barrier can go either to or from humans, and that the human being is just one more species in this regard. Other viruses that have recently emerged to affect new species are several variants of the genus Henipavirus, infecting bats in Southeast Asia (Nipah virus) and Oceania (Hendra virus; Eaton et al., 2006). In recent years an increase in fatal cases by these viruses in humans and livestock (pigs and horses) has been observed, but an inefficient transmission between individuals of these species has prevented further spread in the human and/or livestock populations. However, in a recent outbreak of Nipah virus occurring in Bangladesh it appeared that an efficient transmission occurred between humans (Gurley et al., 2007). Finally, it is important to note that there is probably a species barrier crossing after every first diagnosis of a viral emerging disease, even though the natural reservoir might remain unknown. In 2003, the first cases of what appeared to be a new disease entity with fatal consequences for affected humans, were diagnosed in Hong Kong. It received the name of severe acute respiratory syndrome (SARS) and caused a great social concern worldwide, particularly when clusters of cases were detected in up to a dozen countries in three continents around the world, although a rapid response prevented further spread. The causative agent of this disease, named SARS virus, was identified during earlier investigations (Drosten et al., 2003; Kuiken et al., 2003), but its natural host remained unknown until Rhinolophidae (horseshoe bats) species were identified as reservoir hosts (Li et al., 2005; Cui et al., 2007).

\section{INFLUENCE OF THE ENVIRONMENT IN INFECTIOUS DISEASES}

The environment of viruses is constituted essentially by the cells they infect. Viruses must parasitize cells to ensure their propagation. Outside cells, viruses lack of activity, although to allow transmission to another individual they need to survive outside the cell. The way a virus survives in the environment is the result 
of an adaptation that largely determines how it is transmitted. Viruses can be transmitted through direct contact between individuals, or through other ways such as, for instance air, water, feces, body fluids, food, or fomites. In some cases, transmission needs the participation of other living organisms, so-called vectors, in which the virus is equally propagated. These vectors are often blood-sucking insects that inoculate the infectious pathogen through their bites, thus spreading the infection in a population. A virus may preferably use a single transmission route, but viruses using more than one way of transmission are frequent.

The progress of a viral infection in a population is a multifactorial process, depending on a range of both biotic and abiotic factors. These factors and their influence on the development and transmission of the infection at the population level constitute the eco-epidemiology of an infectious disease. There is a strong relationship between the route of transmission and the ecoepidemiology of a given infectious disease. For example, the spread of infections that are transmitted by direct contact largely depends on the population density, which determines the distance between infected and susceptible individuals. For airborne infections, temperature, humidity, and wind can have a significant influence on the progress of the epidemic. Waterborne and foodborne viruses are usually highly resistant to adverse environmental conditions. A particular case of this type of transmission is represented by the fecal-oral route (often water, food, or objects are contaminated by fecal waste). Viruses that are transmitted through this route have a characteristic resistance to low $\mathrm{pH}$, allowing them to pass through the animal's digestive tract, overcoming the natural barrier that represents the acid secretion of gastric parietal cells. Often, these viruses produce diarrhea, thus being shed in large amounts and returning to the environment, where they can remain infectious for a variable period (up to several months in some instances), depending mainly on environmental temperature (the colder the longer), but also on the presence of salts, organic matter, moisture, solar radiation, etc., until they reach another host and begin the infectious cycle again (Jimenez-Clavero et al., 2005b).

In the case of vector-borne diseases, in addition to pathogen and host, infectious cycle requires a third player: the vector. This fact results in a more complex eco-epidemiology. Habitats of arthropod vectors depend on a number of environmental conditions, including range of temperature, humidity, water availability, etc. Arboviruses (i.e., viruses transmitted by arthropod vectors), are distributed necessarily in areas where populations of competent vectors (i.e., vectors which are able to spread the disease to new hosts) are abundant enough. Each arthropod vector species occupies a particular ecological niche within specific environmental conditions, so that its distribution can be greatly affected by changes in temperature, rainfall, humidity, plant coverage, etc. (Randolph and Rogers, 2010; Weaver and Reisen, 2010).

In summary, environmental variations constitute an important factor in the occurrence and spread of infectious diseases in general. This is particularly important for arthropod-borne diseases, where environmental changes can influence both their geographic range and the risk of introduction (Sutherst, 2004; Gould and Higgs, 2009; Tabachnick, 2010).

\section{EMERGING INFECTIOUS DISEASES AND GLOBAL CHANGE}

The Planet Earth is in continuous change. Environmental changes are driven by both abiotic and biotic factors. Of these, impact caused by humans has gained importance as the human population has risen, from the local level to reach a global scale (Meadows et al., 1972). Global change is defined as the impact of human activity on the fundamental mechanisms operating in the biosphere (Duarte, 2006). Global change comprises not only impacts on climate, but also on the water cycle, land use, biodiversity loss, invasion of alien species into new territories, introduction of new chemicals in Nature, etc. The influence of global change on emerging infectious diseases has been the subject of different revisions (Fayer, 2000; Weiss and McMichael, 2004; Wilcox and Gubler, 2005; Patz et al., 2008). As noted above, environmental changes largely determine the evolution of many emerging infectious diseases, most notably arthropod-borne ones (see reviews by Sutherst, 2004; Gould and Higgs, 2009; Tabachnick, 2010), Therefore, climate changes will impact necessarily on these diseases (Rosenthal, 2009). However, there are many other driving factors - not only those related to climate changes - that have or have had a powerful influence on the occurrence or change of many infectious diseases. Table 1 shows some of these drivers, identified as relevant in the emergence and re-emergence of infectious diseases in a recent study (Woolhouse and Gowtage-Sequeria, 2005). It is not the purpose of this article to review systematically all these factors, which have been reviewed elsewhere (Smolinski et al., 2003; Woolhouse and Gowtage-Sequeria, 2005) but to briefly expose some examples, in order to highlight their relative importance in the emergence of infectious diseases in an overall context of globalization.

For instance, intercontinental transport by air makes it possible to move persons and goods thousands of miles away within few hours. For a person who has just acquired an infection it is possible to arrive to destination even within the incubation period,

\begin{tabular}{|c|c|}
\hline Rank* & Driver \\
\hline 1 & Changes in land use or agricultural practices \\
\hline 2 & Changes in human demographics and society \\
\hline 3 & Poor population health (e.g., HIV, malnutrition) \\
\hline 4 & Hospitals and medical procedures \\
\hline 5 & $\begin{array}{l}\text { Pathogen evolution (e.g., antimicrobial drug resistance, increased } \\
\text { virulence) }\end{array}$ \\
\hline 6 & Contamination of food sources or water supplies \\
\hline 7 & International travel \\
\hline 8 & Failure of public health programs \\
\hline 9 & International trade \\
\hline 10 & Climate change \\
\hline
\end{tabular}

* Ranked by the number of pathogen species associated with them (most to least). 
and develop (and transmit) the disease upon arrival, resulting in an "imported disease." This not only applies to people, but occurs similarly as a result of trade of live animals and their products, an important economic activity worldwide, which is subjected to strict regulations (OIE, 2011) that must be implemented in coordination with all countries, precisely to prevent the spread of infectious diseases harmful to livestock, which in this context are called "exotic" or "transboundary" diseases. However, these rules have been insufficient to halt the spread of many infectious animal diseases of tremendous economic impact, partly because control and surveillance systems do not always work effectively. As an example of what an effective control can achieve, it is worth to mention what constituted the first detection in Europe of highly pathogenic avian influenza virus H5N1 from Asia, which occurred in 2004 at a border checkpoint in the airport of Brussels (Belgium). Customs officers detected in the luggage of a traveler from Thailand two mountain hawk eagles (Spizaetus nipalensis) alive, apparently brought as a gift. The two birds were found to be infected with the virus (Van Borm et al., 2005). This case also reminds that, in addition to the above, illegal trafficking of animals, including exotic species, must also be considered as a relevant factor involved in importation of transboundary diseases. A good example was given in 2003 by the occurrence of outbreaks of monkeypox in humans in the U.S., originated as a result of illegal import of infected exotic rodents from Ghana (Guarner et al., 2004). The disease has reached local populations of rodents (prairie dogs, Cynomys spp.).

Regarding arboviral diseases, the impact of trade and transport on the distribution of vectors is reflected by the global expansion of the tiger mosquito (Aedes albopictus), associated with trade in used tires (Reiter and Sprenger, 1987) or in Dracaena plants ("lucky bamboo"; Madon et al., 2002). Rain causes small pools of water inside the tires stored outdoors. This constitutes an excellent breeding habitat for this mosquito, because it mimics the hollow trunks of rainforest trees that are its natural habitat. Through transport of used tires containing A. albopictus eggs, this mosquito has reached a worldwide distribution. This mosquito is a competent vector of many pathogens, including dengue, yellow fever, chikungunya, Venezuelan equine encephalitis, and WNF (Paupy et al., 2009; Weaver and Reisen, 2010).

Other factors derived from human activities linked to the emergence of infectious diseases are those related to land use: a growing human population is demanding more resources necessary for its supply and welfare, particularly food, but also energy, raw materials, water, urban land, etc. New agricultural plantations and livestock grazing plots on deforested lands promote the emergence and/or spread of infectious diseases hitherto confined to the forest habitat (Smolinski et al., 2003; Woolhouse and Gowtage-Sequeria, 2005).

Deforestation and biodiversity loss are often cited as causes of increased incidence of emerging infections in certain regions. An example can be found in the emergence of Junin virus in Argentina (Charrel and de Lamballerie, 2003). Changes in water use are, nonetheless, one of the factors most clearly related to the modification of eco-epidemiological patterns accompanying emerging infectious diseases. New irrigation plans, construction of dams, etc. have a direct effect on the abundance of competent vectors for transmission of various arboviruses. The new irrigation in northwestern Australia seem to be the main cause of the recent expansion of Murray Valley fever, an emerging zoonotic arbovirus in that country (Mackenzie etal., 2004). The construction of dams may have caused an important impact on the recent emergence of Rift Valley fever in East Africa, causing highly virulent outbreaks for both man and livestock, by allowing a dramatic increase in mosquito populations involved in transmission (Martin et al., 2008).

Healthcare is another area of human activity that, somehow paradoxically, is linked in many instances to infectious disease emergence. Iatrogenic transmission of infectious diseases, through transfusions, transplants, and other medical interventions, has undoubtedly had an effect on the expansion of certain pathogens such as hepatitis C virus (Alter, 2002; Prati, 2006). Fortunately, current medical practice has reduced this risk very significantly (Alter, 2002; Prati, 2006). The administration of biologicals derived from animals or animal cell cultures, such as vaccines and therapeutic products, can also act as a vehicle for the transmission of pathogens (Parkman, 1996). Despite strict controls on each batch of vaccine for the presence of certain pathogens, there have been cases of transmission of adventitious viruses in contaminated vaccines. One of the best known cases of this kind is represented by bovine viral diarrhea virus (BVDV), a pestivirus affecting cattle. In the manufacturing process of many vaccines, cell cultures are widely employed, and fetal calf serum is used as an additive common to cell culture media. BVDV is highly prevalent in cattle and certain variants of the virus remain unnoticed in cell cultures. In some cases, batches of fetal calf serum from BVDV-infected animals were used inadvertently, resulting in viral contamination of vaccines. Some of them (those addressed to the bovine, such as vaccine against bovine herpesvirus type 1) eventually resulted in outbreaks of viral diarrhea in vaccinated cattle, which alerted for the presence of the virus (Makoschey et al., 2003). Currently, regulatory agencies, such as the European Medicines Agency, have modified their safety requirements to control specifically the risk of contamination by animal pestiviruses in drugs and vaccines.

\section{CLIMATE CHANGE AND EMERGING INFECTIOUS DISEASES}

Global warming is the rise in average surface temperature of the earth observed in the last decades $\left(+0.6^{\circ} \mathrm{C}\right.$ in the last half century; IPPC, 2007). This observation applies also specifically to Europe (EEA, 2012) and North America (Karoly et al., 2003), territories particularly concerned to WNV and BT virus (BTV) emergences, as it will be discussed later. The increase has accelerated in recent years and is expected to go faster, so that in the twenty-first century the average surface temperature of the earth is expected to rise in a range between +1.6 and $+6^{\circ} \mathrm{C}$, depending on the different scenarios considered (IPPC, 2007). Although still a contentious issue, most scientists now accept that human activity has contributed to the observed global warming (Oreskes, 2004), mostly through emissions of greenhouse gases produced by industrial activity and consumption of fossil fuels for transport, energy production, etc. (IPPC, 2007). The impact of global warming on the environment is the subject of numerous recent studies, based on predictive modeling scenarios depending on the 
level of emissions. It is not the purpose of this article to review these models, which are described extensively elsewhere (IPPC, 2001,2007), but to highlight some future climate trends, mainly in Europe, the scenario for some recent unusual observations regarding arboviral diseases (Purse et al., 2008; Wilson and Mellor, 2009; Zientara et al., 2009; Calistri et al., 2010; MacLachlan and Guthrie, 2010; Sotelo et al., 2011a). For this, I will rely on data from the European project PRUDENCE (Prediction of Regional scenarios and Uncertainties for Defining EuropeaN Climate change risks and Effects; Christensen, 2005). Table 2 summarizes the most marked trends for Europe in the next 100 years according to this study. In addition to an increase in mean annual air temperature, predicted to be between 1.4 and $4.5^{\circ} \mathrm{C}$, depending on the areas (the highest rise is expected to occur in the Iberian Peninsula), the study suggests there will be more droughts, more wildfires, heat waves will be more frequent, and all this will be particularly noticeable in southern Europe. Winters will become milder, and this will occur more rapidly in northern latitudes. As a result, frost will decrease, and minimum temperatures will rise. These circumstances favor living cycles of certain arthropod vectors, which in these conditions will be able to overwinter more easily in latitudes and areas beyond their current geographic ranges. Other remarkable trends include rising temperatures and unusually hot summers, but also greater interannual variability, particularly in central Europe, which will make adaptations more difficult. Waves of extreme temperatures (both cold and heat) will become more frequent. With regard to rainfall, the

Table 2 | Long-term climatic trends in Europe, based on data from PRUDENCE* (Prediction of Regional scenarios and Uncertainties for Defining EuropeaN Climate change risks and Effects;

Christensen, 2005).

\begin{tabular}{ll}
\hline Parameter & Trend \\
\hline Air temperature & Rise in air temperature \\
Winter temperature & Milder winters \\
Seasonal variation & Less seasonal variation \\
Drought stress & Higher drought stress \\
Forest fires & More forest fires \\
Night-time temperatures (frost) & Warmer night-time temperatures \\
Heat waves & More days of extreme heat and heat \\
& waves in summer, and more year-to-year \\
& variability \\
Very hot summers & Unusually hot summers more frequent \\
Rainfall & Rainfall: increase in the North and \\
& decline in the South \\
Snow & Snow: decline \\
Floods & Floods: more frequent \\
Strong winds & Higher frequency of hurricanes/cyclones \\
(hurricanes/cyclones) & with extreme strength
\end{tabular}

*PRUDENCE was a project funded by the European Commission under its fifth framework programme. It had 21 participating institutions from a total of 9 European countries. For further information, see PRUDENCE: http://prudence.dmi.dk/ tendency is to increase in northern Europe and decrease in the South. Therefore, increasingly severe droughts are expected in southern Europe, with a considerable impact on agriculture and water resources. However, torrential rains, especially in summer, will become more common throughout Europe, causing flooding to occur more frequently. Snow will become rarer. River flows will decrease in the South, and increase in northern Europe. Extreme wind events (hurricanes, cyclones) will also be more frequent.

How will these climate changes impact on emerging infectious diseases? The consequences of global warming are expected to be diverse and highly variable in different geographical locations. For example, as noted above, the effects of climate change in Europe will differ significantly between northern and southern latitudes, and these differences could even be greater at the local level, although they will not be easily distinguished from weather variations. These changes may affect disease emergence not only through direct effects on populations of vectors, reservoirs, and hosts, but also indirectly, through, for instance, induced changes in human activities. For instance, in a scenario like that depicted in the predictive climatic models above cited for southern Europe, lower rainfall, increased temperature, and reduced water availability will have important consequences not only on agricultural activities which, as already noted, have a major impact on infectious diseases, but for example on tourism, which is the main source of wealth in these regions. A significant decline in economic activity could lead to a decrease in population, food demand, and hence livestock. In this changing context, plenty of uncertainties, it is difficult to predict an overall trend: some infectious diseases will probably emerge, some existing ones will spread, and others may disappear. Even in specific cases a disease may be exacerbated transiently and disappear later. For example, the cease of agricultural production in irrigation areas, which can likely occur in a scenario of extreme drought, could lead at long-term to local extinction of mosquito-borne diseases, whose breeding habitat depends on the infrastructure dedicated to this type of agriculture. However, disuse and neglect could favor the accumulation of organic matter in certain points of these infrastructures, turning them into optimal habitats for breeding of vectors, something that the normal maintenance of the network usually avoids. This would likely lead to a transient increase in the incidence of certain diseases, although prolonged drought would eventually lead these vectors to extinction.

The effects of climate change are beginning to be perceived, and at the same time remarkable changes in the geographic range and incidence of some infectious diseases are being observed, suggesting some kind of relationship, which is difficult to ascertain. As remarked above, climate change is not the only factor influencing infectious disease emergence, as there are other components in the global change which have also important effects on disease emergence. The following sections deal with two of the emerging arboviral diseases of animals that have changed more radically their epidemiological patterns in recent years: BT and WNF (Zientara et al., 2009). Climate, weather and other factors related to global change which are potentially involved in disease emergence will be examined specifically for each of these two diseases. 


\section{BLUETONGUE}

\section{THE VIRUS AND THE DISEASE}

Bluetongue is a non-contagious infectious disease of ruminants (reviewed in MacLachlan, 1994; Wilson and Mellor, 2009; MacLachlan, 2011). Mainly affects sheep, particularly some selected European breeds. Cattle and goats act as reservoirs of the virus, which infect these animals usually producing a milder disease, often asymptomatic. The disease can affect also wild ruminants, severely in some species. BT is an economically important disease for livestock, included in the list of notifiable diseases to the OIE (World Organization for Animal Health) and is therefore subject to strict regulations regarding the trade of animals and their products (OIE, 2011), causing severe economic losses in the affected countries.

Clinical manifestations range from subclinical infection to acute illness that can be fatal. Expression of BT disease reflects a variety of virus, host, and vector factors (MacLachlan, 2004). Clinical signs in sheep include pyrexia, tachypnea, nasal discharge, and lethargy. Pathology is characterized by generalized edema, hemorrhage, especially in lymph nodes, lungs, heart, and skeletal muscle and necrosis on the surface of the oro-nasal mucosa and gastro-intestinal tract (reviewed in MacLachlan et al., 2009).

The causative agent, BTV, belongs to the family Reoviridae, genus Orbivirus, has a genome of segmented doublestranded RNA (dsRNA), contained in a non-enveloped capsid shell (reviewed in Schwartz-Cornil et al., 2008). Its main route of transmission is through the bite of midges of the genus Culicoides. The BTV genome is divided into 10 dsRNA segments which encode seven structural (VP1-VP7) and four non-structural (NS1, NS2, NS3, and NS3a) proteins. BTV is closely related to other orbiviruses such as African horse sickness virus (AHSV) and epizootic hemorrhagic disease of deer virus (EHDV), to which it shares not only physico-chemical characteristics but also eco-epidemiology and vector type, although differing in host range. As for now, 26 serotypes of BTV have been described (two of them very recently; Hofmann et al., 2008; Maan et al., 2011), with no cross-protective immunity between them. Within each serotype there is also a great variability, largely facilitated by the segmented genome, allowing genetic "reassortment." This enables these viruses to generate multiple variants that may differ in important characteristics or phenotypes, such as pathogenesis, host range, vector competence, or transmissibility (MacLachlan, 2004).

Viremia is transient, starting at 3-5 days after infection in sheep somewhat later in other ruminants, peaking at about 7-10 days, declining slowly thereafter (Darpel et al., 2007). The duration of viremia is variable, depending on the species affected, and can last for 5-6 weeks in sheep, up to 8 weeks in cattle (MacLachlan et al., 1994; Bonneau et al., 2002). Virus detection in blood is commonly used as a proof of infection in diagnostic tests based in specific reverse transcription-polymerase chain reaction (RT-PCR) methods (Jimenez-Clavero et al., 2006). The host's immune system responds to infection by generating serotypespecific neutralizing antibodies, which are widely recognized as key factors in the long-term protective response against infection (Schwartz-Cornil et al., 2008). Seroconversion occurs between 1 and 2 weeks after infection. Serogroup-specific antibodies are directed primarily to the VP7 protein of the virus capsid, which are commonly detected by enzyme immunoassay (ELISA) employing recombinant VP7 antigen (Afshar et al., 1992; Mecham and Wilson, 2004), while serotype-specific neutralizing antibodies (which are detected by specific neutralization tests) recognize epitopes in the VP2 capsid protein (DeMaula et al., 1993; Pierce et al., 1995). The presence of specific antibodies in serum samples is another common diagnostic test, which indicates that infection has occurred, or that the animal has been vaccinated. There are live attenuated and inactivated vaccines, which are specific for each serotype.

\section{BLUETONGUE ECO-EPIDEMIOLOGY}

Survival and transmission of BT in an area requires the presence of Culicoides vectors. To be transmitted, BTV must infect a competent Culicoides vector. In this process the vector acquires the infection by feeding on blood from a viremic host, then the virus multiplies and disseminates throughout the vector body, reaching the salivary glands, ready to be inoculated in the next host after biting on a further blood feed. There is no transovarial transmission of the virus. There are approximately 1,500 known species of Culicoides midges, of which about 50 have been shown to be competent for BTV transmission (Wilson and Mellor, 2009). In different endemic areas, BTV is transmitted through one or a few distinct local Culicoides species. For example, in North America this species is Culicoides sonorensis, while in southern Europe and Africa Culicoides imicola is the dominant vector. The distribution and abundance of Culicoides species involved in BTV transmission matches with the distribution of the disease in endemic areas (Mellor and Wittmann, 2002). It also depicts the maps of areas at risk for its introduction. Similarly, seasonality strongly influences vector populations throughout the year, and this determines the periods of occurrence of disease cases (Mellor and Wittmann, 2002). For instance, in temperate zones of the northern Hemisphere most cases of disease occur between August and November, coinciding with the period of greatest abundance of vectors. Among the key factors linking weather to BTV epidemiology, temperature has a crucial influence on vector survival, which, as noted above, directly affects disease occurrence, transmission, and spread. For example, the mean survival time of a Culicoides midge depends on the temperature, i.e., survive longer at lower temperatures (Veronesi et al., 2009). By contrast, higher temperatures promote breeding and feeding of the vectors, which increases virogenesis and transmission of BTV (Wilson and Mellor, 2009). The optimal range of temperature lies between 13 and $35^{\circ} \mathrm{C}$. However, excessively high (above $\left.40^{\circ} \mathrm{C}\right)$ or low $\left(<0^{\circ} \mathrm{C}\right)$ temperatures are lethal in a short period of time. Between 0 and $13^{\circ} \mathrm{C}$ Culicoides midges remain in a state of dormancy that allows them to survive until more favorable temperatures allow resuming their activity. Relative humidity is also a key factor in Culicoides life cycle (Wittmann et al., 2002). The mentioned temperature ranges are valid only above a minimum relative humidity. Winter survival (overwintering) is crucial for the maintenance and consolidation of the presence of BTV in a geographic area. Midge survival is favored by mild, frost-free, winters. Wind is another important factor that links weather to BTV eco-epidemiology. Wind blows can drag swarms of Culicoides midges, and bring them hundreds 
of kilometers away. This mechanism has been widely recognized as an important way Culicoides (and BTV, if present in the vectors) spread, bridging distances up to $700 \mathrm{~km}$ under favorable conditions (Carpenter et al., 2009; MacLachlan and Guthrie, 2010). This form of dispersal is the most likely way BTV has reached the shores of southern Europe from Africa in many occasions in the last years (Wilson and Mellor, 2009).

As noted above, though primarily pathogenic in sheep (particularly in some selected breeds) BTV can infect a variety of ruminants, where the disease often remains asymptomatic. For the transmission to occur the virus must replicate in the host to reach a minimum level of viremia which enables it to be ingested in sufficient amount in a blood feed of a Culicoides vector to be able to replicate in it. Camels also seem to act as reservoirs (Batten et al., 2011), possibly playing a role in the spread of the disease by facilitating the virus to get through the "sand barrier" represented by the Sahara desert, which stands between the tropics and subtropics (where BTV is endemic), and North Africa and Europe where it causes epizootics periodically. This role for camels not only for BT, but also for other epizootic arboviral diseases is supported by recent serological evidence (El-Harrak et al., 2011; Touil et al., 2012). South American camelids are susceptible to the infection, but develop only a mild form of the disease (Schulz et al., 2012). A wide range of wild ruminant species are susceptible to BTV infection, but only a few suffer from severe disease, including white-tailed deer (Falconi et al., 2011) and mouflon (FernandezPacheco et al., 2008; Lopez-Olvera et al., 2010). The role of wild ruminants in the eco-epidemiology of BTV is less known.

\section{BLUETONGUE: PAST AND PRESENT}

Bluetongue was first described in South Africa in the eighteenth century, affecting imported merino sheep (MacLachlan and Guthrie, 2010). Outside Africa, BTV was detected for the first time in Cyprus in 1943. Shortly after it was found in North America, Middle East, Australia, and Asia, as an endemic disease affecting tropical and subtropical areas with epizootic incursions in temperate zones where the presence of competent vectors allowed its transmission (MacLachlan, 2004). Traditionally, its natural geographic range was considered to be located between latitudes $35^{\circ} \mathrm{S}$ and $40^{\circ} \mathrm{N}$. In Europe, regions with suitable conditions for incursions of BT were the south of the Iberian and Italian Peninsulas and some islands of the Aegean Sea, where climate and presence of competent vectors, along with the proximity to endemic areas (Middle East and Africa) contributed to create an area at high risk of entry of the disease (reviewed in Mellor and Wittmann, 2002; Mellor et al., 2008). In 1956, BT burst into the Iberian Peninsula from Africa, causing major losses in sheep. However, apart from this episode and some subsequent incursions in Cyprus and the Greek islands of Lesbos and Rhodes, Europe had remained free of this disease, which was considered "exotic" in this continent. This situation began changing after 1998, with increasingly frequent outbreaks in the Mediterranean islands and in southern continental Europe (Mellor and Wittmann, 2002; Mellor et al., 2008). A parallel upsurge was observed meanwhile in the Middle East and the North of Africa. Between 1998 and 2001, BT outbreaks were declared in the territories of Greece, Bulgaria, Turkey, Macedonia, Serbia, Croatia, Montenegro, Bosnia-Herzegovina,
Albania, Italy, France, and Spain. BTVs involved belonged to at least five different serotypes $(1,2,4,9$, and 16). Four of them $(1,2,9$, and 16) came from the East (Middle East), and two more introductions from the South (Africa) involved serotypes 2 and 4 (Mellor et al., 2008). Even during this period the disease showed some expansion to the North, breaking the northern limit of the disease in Europe, represented by latitude $40^{\circ} \mathrm{N}$, with some outbreaks occurring near $45^{\circ} \mathrm{N}$ in the Balkans. Since then, BT is considered an emerging disease in Europe (Wilson and Mellor, 2009). But the quantum leap in the epidemiology of the disease in Europe was to take place in August 2006 when an outbreak of BT was declared in the Netherlands at the Maastricht region. The virus isolated in this outbreak belonged to serotype 8 , and was the first occurrence of this serotype in Europe (Wilson and Mellor, 2009). The disease has since spread with unprecedented speed and virulence, affecting first Holland, Belgium, Luxembourg, France, and Germany, and expanding rapidly into the UK, Austria, Czech Republic, Switzerland, Denmark, Italy, and Spain (Saegerman et al., 2008). Since then the virus showed its ability to overwinter in unusually high latitudes, remaining present in most of Europe, and even spreading to other European countries such as Hungary, Norway, and Sweden. The number of outbreaks produced by this BTV8 in Europe since its first detection in 2006 is 89,136 (EUBTNET, 2011). The incidence of the disease peaked in 2007 with 50,479 outbreaks declared. Massive vaccination campaigns, initiated in 2008, contributed largely to control the disease, so that the number of outbreaks were drastically reduced since 2009, and practically disappeared in 2010 and 2011 (EUBTNET, 2011). The epidemic of BTV8 in Europe was unusual not only because of the latitude in which it occurred, immediately suggesting that vectors involved in transmission should be different from those "expected" and more common in southern Europe (C. imicola). In fact, it appears that the BTV8 responsible for the epidemic was adapted to midge species more common in northern Europe, such as those of the C. obsoletus complex (Wilson and Mellor, 2008). Another remarkable characteristic of this virus is its special virulence and pathogenicity, which also affected cattle. In addition, this virus seems able to be transmitted to the fetus through the placenta, a feature that had only been observed in infections with attenuated BTV vaccine strains, and never in BTV field strains (MacLachlan et al., 2009). These unusual characteristics illustrate perfectly the principle of emerging viruses arising from an underlying pool of varying viruses, with new properties that may result in new ecological and epidemiological patterns of a viral disease.

But recent occurrence of BT in Europe has not been limited to the, otherwise outstanding, BTV8 epizootic. Other serotypes have reached the shores of the southern European countries and caused severe harm to livestock in these years (Mellor and Wittmann, 2002; Saegerman et al., 2008). Of particular relevance were the incursions of BTV serotype 4 in Spain, Italy, and the western Mediterranean islands in 2003-2004, and the entry of a particularly highly pathogenic strain of BTV serotype 1 first in Sardinia (Italy) in 2006, and then in Spain in 2007, which extended rapidly to Portugal and France, causing also many thousands of outbreaks in these countries. The same strategy adopted to fight against the BTV8 epizootic, based on vaccination campaigns, was used 
simultaneously against BTV1 and BTV4, with the same success at reducing disease incidence to almost negligible (Wilson and Mellor, 2009). Currently, new incursions of different BTVs continue threatening Europe, a continent that will no longer be considered out of reach of BT.

\section{BLUETONGUE: FUTURE TRENDS}

In the past 15 years very significant qualitative changes have occurred with regard to the epidemiology of BT, which has reached unprecedented severity in Europe (Wilson and Mellor, 2008, 2009; Zientara et al., 2009). Some important trends observed in this period are: (1) a major increase in the frequency of BTV incursion events in Europe, (2) a geographic expansion of the disease, reaching latitudes close to parallel $55^{\circ} \mathrm{N}$, i.e., $15^{\circ}$ beyond the classic northern distribution limit for BT in Europe, (3) an ability to overwinter in locations a priori unsuitable for known competent vectors, (4) changes in some strains with regard to their pathogenicity (BTV1 strain is highly pathogenic in sheep; unpublished observation) and host range (BTV8 strain is pathogenic in European bovine), and (5) new ways of transmission (BTV8 strain can be transmitted transplacentally, affecting fetuses and newborn cattle).

What is the explanation for all these changes? Undoubtedly, the rising temperature in Europe in recent years (EEA, 2012) is a factor having a major influence in this situation (Purse etal., 2008; Wilson and Mellor, 2008). Particularly, unusually mild winters that occurred in 2006-2007 and 2007-2008 in the affected areas have probably favored the habitat of certain Culicoides species that could act as vectors in these regions, promoting their geographical expansion. Some studies indicate that the distribution of C. imicola, the principal vector of BTV in southern Europe, has undergone a geographic expansion, reaching areas where it had never been observed, for example the North of Spain (Goldarazena etal., 2008), although some authors have not observed expansions of this vector in Italy in recent years (Conte et al., 2009). Nevertheless, in northern and central Europe, competent vector species must be different, because $C$. imicola is not present in these areas (Saegerman et al., 2008). Other likely competent vectors for BT which are present in Europe are C. obsoletus, C. pulicaris, C. scoticus, and C. dewulfii (Saegerman et al., 2008). For some of these vector species, their vectorial capacity for BT transmission was considered secondary or even irrelevant, as compared to C. imicola. However, changes in circulating viruses involving adaptations to some of these vectors may have improved this capability. On the other hand, it is a wellknown fact that the temperature can affect vector competence, effectively increasing it above a certain temperature threshold (Wilson and Mellor, 2009).

But climate change alone is insufficient to explain the whole picture regarding the current rise of BT in Europe. First, I have already mentioned how the wind can drag swarms of infected Culicoides, spreading the disease to considerable distances, and that this is likely route of entry of BT in southern Europe (Ducheyne et al., 2007), though animal movements could also play a role. I have also mentioned how camels could act as carriers for these viruses from sub-Saharan Africa to North Africa, where BT is often detected some time before affecting Europe (Touil et al., 2012). But how was BTV8 introduced into northern Europe? Unlike other strains that have invaded Europe in recent years, this BTV-8 strain has not previously been detected in the North of Africa or the Middle East. Among the few sequence data available to date on relevant BTV strains, it has been shown that the most similar virus found is a strain from sub-Saharan Africa (Nigeria) isolated in 1982 (Maan et al., 2008). This "gap" in space and time indicates clearly that more sequence data from relevant BTV sources are needed to draw any conclusion about the origin of the European BTV-8 strain. As already discussed in the previous section, the trade of animals and animal products, as well as of wildlife (either legal or illegal), may be behind many accidental introductions of infectious diseases, and this hypothesis should be taken into account in this case, although thus far, no evidence has been obtained neither for nor against it (Mintiens et al., 2008). Other questions remaining where climate change does not provide a full explanation are (1) the virus ability to overwinter in extremely cold conditions such as those found in certain areas of northern Europe, (2) the role that vertical transmission may have on its survival, and (3) phenotypic changes perceived in some recent BTV variants, which are more pathogenic and/or affect other species such as cattle. More research is needed to find answers to these questions.

Bluetongue is no longer a tropical disease, exotic, typical of warm countries, but it has come to stay in Europe. This radical change cannot be understood without taking into account global changes that are taking place in the world of which climate change plays an important role. Current knowledge indicates that this climatic change will become increasingly intense in the future, which, at least in theory, would favor the spread of BT, although other factors may also modulate this trend.

\section{WEST NILE FEVER/ENCEPHALITIS THE VIRUS AND THE DISEASE}

West Nile virus is the etiological agent of an emerging zoonotic disease whose impact on animal and public health is considerable, being the most widespread arbovirus in the world today (reviewed in Hayes et al., 2005a; Kramer et al., 2008; Brault, 2009). A percentage of WNV infections result in severe encephalitis, and it is a communicable disease both for human and animal health. WNV taxonomically belongs to the family Flaviviridae, genus Flavivirus. Virions are spherical in shape, about $50 \mathrm{~nm}$ in diameter, and consist of a lipid bilayer that surrounds a nucleocapsid that in turn encloses the genome, a unique single-stranded RNA molecule, which encodes a polyprotein that is processed to give the 10 viral proteins. Of them, three (C, E, and $\mathrm{M})$ form part of the structure of the virion, and the rest (NS1, NS2a, NS2b, NS3, NS4a, NS4b, and NS5) are so-called "non-structural" and play important roles in the intracellular processes of replication, morphogenesis, and virus assembly. Inserted into the lipid bilayer are two proteins, E (from "envelope") and M ("matrix"), which participate in important biological properties of the virus, such as its host range, tissue tropism, replication, assembly, and stimulation of cellular and humoral immune responses. E protein contains the major antigenic determinants of the virus.

As far as we know, there are no serotypes of WNV, but two main genetic variants or lineages can be distinguished, namely lineages 
1 and 2. While the former is widely distributed in Europe, Africa, America, Asia, and Oceania, the second is found mostly restricted to Africa and Madagascar, although it has recently been introduced in Central and Eastern Europe (Bakonyi et al., 2006; Platonov et al., 2008) and has further extended to southern Europe (Bagnarelli et al., 2011; Papa et al., 2011). In addition, other viral variants closely related phylogenetically to $\mathrm{WNV}$ have been described, which are different from lineages 1 and 2, and have been proposed as additional WNV lineages. One of them, known as "Rabensburg virus," isolated form mosquitoes in the Czech Republic in 1997, shows low pathogenicity in mice (Bakonyi et al., 2005). Similarly, other viruses closely related to WNV have been isolated in India (Bondre et al., 2007), Russia (Lvov et al., 2004) Malaysia (Scherret et al., 2001), and Spain (Vazquez et al., 2010). All these viruses have been proposed to represent different genetic lineages of WNV. Except for the Indian variant, which has been involved in outbreaks of encephalitis in humans, the rest are of unknown relevance for animal and human health.

West Nile fever/encephalitis is a disease transmitted mainly by mosquitoes, while wild birds are its natural reservoir. WNV is capable of infecting a wide range of bird species. Nevertheless, birds were considered less susceptible to the disease until the recent epidemic of WNV in North America, affecting many species of birds lethally, made to re-examine this concept (Komar et al., 2003). Occasionally it may affect poultry species, mainly geese and ostriches. Other domestic birds like chickens and pigeons, are susceptible to infection but do not get sick, and are often used as sentinels for disease surveillance. In addition to birds, WNV can also affect a wide range of vertebrates species, including amphibians, reptiles, and mammals, and it is particularly pathogenic in humans and horses, which act epidemiologically as "dead end hosts," that is, they are susceptible to infection but do not transmit the virus (McLean et al., 2002; Kramer et al., 2008).

The first case of WNF was described in Uganda (West Nile district, hence the name of the virus) in a feverish woman, from whose blood the virus was first isolated in 1937 (Smithburn et al., 1940). It was considered a mild disease, endemic in parts of Africa (an "African fever"). However, since around 1950s, the occurrence of disease outbreaks with neurological disease, lethal in some cases, caused by WNV, especially in the Middle East and North Africa, made necessary to rethink this concept. In humans, the majority of WNV infections are asymptomatic, about 20\% may develop mild symptoms such as headache, fever, and muscle pain, and less than $1 \%$ develop more severe disease, characterized by neurological symptoms, including encephalitis, meningitis, flaccid paralysis, and occasionally severe muscle weakness (Hayes et al., 2005b). Advanced age is considered a risk factor for developing severe WNV infection or death. The mortality rate calculated for the recent epidemic of the disease in the U.S. is 1 in every 24 human cases diagnosed (Kramer et al., 2008).

In horses (reviewed in Castillo-Olivares and Wood, 2004) neurological disease is manifested by approximately $10 \%$ of infections, and is mainly characterized by muscle weakness, ataxia, paresis, and paralysis of the limbs, as a result of nerve damage in the spinal cord. They may also suffer from fever and anorexia, tremors and muscle stiffness, facial nerve palsy, paresis of the tongue, and dysphagia, as a result of affection of the cranial nerves. A proportion of horses infected with WNV die spontaneously or is slaughtered to avoid excessive suffering. The mortality rate can vary between outbreaks. For example, in the outbreak in 2000 in the Camargue (France), 76 horses were affected, of which 21 died (Zeller and Schuffenecker, 2004). In 1996 in Morocco, a WNV outbreak affected 94 horses, of which 42 died (Zeller and Schuffenecker, 2004). Severe equine cases do not seem to predominate in older horses, as occurs in humans (Castillo-Olivares and Wood, 2004). Other mammals may also suffer from the disease. Rodents such as laboratory mice and hamsters are highly susceptible, so they can be used as experimental model of WNV encephalitis. Lemurs and certain types of squirrels appear to be the only mammals capable of maintaining the virus in local circulation (Rodhain et al., 1985; Root et al., 2006). WNV can also infect other mammals, including sheep, in which it causes abortions, but rarely encephalitis (Hubalek and Halouzka, 1999). WNV has been isolated from camels, cows, and dogs in enzootic foci (Hubalek and Halouzka, 1999). The virus has been shown to infect frogs (Rana ridibunda), which in turn are bitten by mosquitoes, so that the existence of an enzootic cycle in these amphibians is postulated, at least for some variants of the virus (Kostiukov et al., 1986). Outbreaks of severe WNF with high mortality have been reported in captive alligators and crocodiles, presumably transmitted through feeding of contaminated meat (Miller et al., 2003). It has been shown experimentally that WNV can infect asymptomatically pigs (Teehee et al., 2005) and dogs (Blackburn et al., 1989; Austgen et al., 2004). However, guinea pigs, rabbits, and adult rats are resistant to infection with WNV (McLean et al., 2002). Among non-human primates, rhesus and bonnet monkeys (but not Cynomolgus macaques and chimpanzees), inoculated with WNV develop fever, ataxia, prostration with occasional encephalitis and tremor in the limbs, paresis or paralysis. The infection can be fatal in these animals.

The virus is propagated in the reservoir hosts, resulting in a viremic phase that usually lasts no more than 5-7 days (Komar et al., 2003). The duration and level of viremia depends on the species infected (Komar et al., 2003). The detection of the virus or its genetic material in serum or cerebrospinal fluid in a laboratory test is a proof of diagnostic value (De Filette et al., 2012). The virus is evidenced by virological (virus isolation) or molecular (RT-PCR-conventional and real-time, NASBA) techniques. In epidemiological surveillance it is useful to detect the presence of WNV in mosquitoes, for which they are homogenized and analyzed using the same methods mentioned above (Trevejo and Eidson, 2008). Specific antibodies against the virus are detectable in blood few days after infection (Komar et al., 2003; De Filette et al., 2012). Antibody detection is performed by serological tests (enzyme immunoassay or ELISA, hemagglutination inhibition or HIT) which can be confirmed by more specific serological techniques (virus-neutralization test; Sotelo et al., 2011c). Serological diagnosis of acute infection should be done by detection of IgM antibodies in serum and/or cerebrospinal fluid using an immunocapture ELISA together with the detection of an increase in antibody titer in paired sera taken one in the acute phase and the other, at least 2 weeks later (Beaty et al., 1989).

The fight against this disease is not straightforward because there are no vaccines licensed for human use, and even though 
there are some available for veterinary use, they are efficacious to prevent disease symptoms and outcome at the individual level but do not prevent the spread of the infection, mainly due to the establishment of an enzootic cycle among wild birds and mosquitoes (Kramer et al., 2008; De Filette et al., 2012). Control methods are mainly based on prevention and early detection of virus spread through epidemiological surveillance and targeted application of insecticides and larvicides (Kramer et al., 2008).

\section{WEST NILE ECO-EPIDEMIOLOGY}

West Nile virus is maintained in nature in an enzootic ("rural" or "sylvatic") cycle between its natural reservoirs, wild birds, and ornithophilic mosquitoes acting as vectors. WNV is a generalist pathogen, as exemplified by the fact that in North America the virus has been found infecting 284 different species of birds and 59 species of mosquitoes, although of these not more than 10 have a relevant role as vectors (Hayes et al., 2005a). This wide host and vector ranges probably facilitate the colonization of vast areas (Kramer et al., 2008). Primary enzootic vectors are most often mosquitoes belonging to the genus Culex, but the virus can be transmitted by mosquitoes of other genera (e.g., Aedes sp.) Transovarial transmission of the virus has been shown to occur in at least some Culex species (Mishra and Mourya, 2001), and this may provide an overwintering mechanism in very cold climates. However, it is not clear whether transovarial transmission takes place as effectively as to allow overwintering. The virus has been repeatedly isolated from ticks, and transmission through tick bites has been shown experimentally (Abbassy et al., 1993; Hutcheson et al., 2005; Formosinho and Santos-Silva, 2006). This has led to the postulation of a role for ticks in overwintering, though this issue needs further studies to be ascertained. WNV can also be transmitted in the absence of vector, using different routes. Firstly, there is experimental evidence of direct transmission in poultry (geese; Banet-Noach et al., 2003). Secondly, carrion birds found infected during periods of absence of vector suggests oral transmission, likely through feeding on contaminated carrion (Garmendia et al., 2000; Dawson et al., 2007). In humans, WNV transmission routes such as intrauterine, lactogenic, and iatrogenic (through transfusions and transplants), are well documented (Hayes et al., 2005b). Occupational exposure of laboratory workers handling contaminated samples has also led to some cases of disease, mostly through cuts or punctures with contaminated material (Hayes et al., 2005b; Venter et al., 2010).

Birds are the natural reservoirs of WNV. Once infected, they are able to replicate the virus in sufficient quantity to enable its transmission to a blood-sucking mosquito. This is not the case of mammals, in general poorly effective as hosts for the virus (Blitvich, 2008). Nevertheless, mammals can be susceptible to the disease to varying degrees. Birds maintain the virus in a rural cycle. In some instances a spillover from this cycle occurs which enables the establishment of a urban cycle, producing outbreaks, sometimes of epidemic character, especially in equines and humans, but also affecting susceptible birds.

West Nile virus is endemic in large parts of Africa, Australia, and India, and more recently (as discussed below) arrived to North America, where since then became endemic. In Europe,
North Africa, and the Middle East the virus has produced occasional outbreaks in areas close to river basins and large wetlands where the presence of vectors (mosquitoes) and reservoirs (birds) provide the optimal conditions for the maintenance of the viral cycle. Short distance spread of the virus to neighboring territories occurs most likely by birds (not necessarily migratory) acting as carriers. The virus can occasionally be spread to long distances by wild bird migrations (Malkinson et al., 2002), although this is not likely a frequent event (Sotelo et al., 2011b), neither it explains all transcontinental translocations of the virus, and significantly, it does not explain the arrival of WNV to North America. Long distance geographic dispersal of WNV by migrating birds is a hypothesis based mainly on circumstantial evidence, such as the discovery of an infected flock of storks in Israel in summer 1998 on their migration back to Africa from central Europe (Malkinson et al., 2002). This hypothesis is supported by molecular phylogenetic studies between isolates from recent outbreaks in Europe and isolates from central Africa, suggesting that birds that migrate between continents may act carrying the virus (Charrel et al., 2003). However, although translocation of WNV (and also other flaviviruses alike, for instance Usutu virus) by bird migration is likely to occur, its frequency does not seem to be as high as to explain every WNV outbreak found in Europe. On the contrary, recent phylogenetic evidence supports that all WNV strains isolated in the western Mediterranean area since 1996 are a monophyletic group arising from a single common ancestor, a strain which could have arrived to this area in 1996 or even earlier, and since then it has been maintained in endemic circulation, evolving and spreading throughout the area (Sotelo et al., 2011b). Finally, one must not assume that the flow of WNV between Europe and Africa operates only in one direction (i.e., from Africa to Europe). The example previously mentioned on migrating storks (Malkinson et al., 2002) as well as specific studies on bird migrations and risk of introduction of pathogens (Jourdain et al., 2007) show that WNV can be translocated from Europe to Africa.

\section{WEST NILE FEVER/ENCEPHALITIS: PAST AND PRESENT}

As already mentioned, in the first half of the twentieth century WNF was considered of little importance due to the benign pathology it caused in endemic areas in equatorial Africa, where it was first isolated and diagnosed. However, after 1951 this concept began to change, as WNV was associated to severe cases of encephalitis, some fatal, in the first epidemic of WNV outside Africa, which occurred in Israel between 1951 and 1957 (Paz, 2006). The virus circulated in Egypt in the same period, where the first eco-epidemiological studies on WNV were carried out. These studies characterized the enzootic cycle of WNV between birds and mosquitoes, identifying men and horses as susceptible to the disease but not transmitting the infection (Taylor et al., 1956). Between 1962 and 1965 there were several outbreaks of severe illness due to WNV in the Camargue, France, affecting both horses and humans. In 1971, WNV was isolated from mosquitoes in southern Portugal, in the course of an epidemiological study starting after an outbreak of encephalitis in horses, in which $29 \%$ of the surviving horses showed seropositivity against WNV. These sporadic outbreaks occurred not only in Mediterranean countries, 
but also in South Africa, Russia, Romania, and India. After that, WNV in Europe remained silent for almost three decades. Its re-emergence took place almost simultaneously in the western Mediterranean (Algeria, 1994; Morocco, 1996; Tunisia, 1997; Italy, 1998, 2008; France, 2000; and Portugal, 2004), in central and eastern Europe (Romania, 1996; Czech Republic, 1997; Russia, 1998; Hungary, 2004; and Austria, 2008), and in the Middle East (Israel, 1998; revisions Hubalek and Halouzka, 1999; Murgue et al., 2001; Sotelo et al., 2011a). Very recently, another lineage of WNV (lineage 2) was detected in central Europe (Hungary, 2004), extended to Austria (2008) and reached the Balkans and Greece in 2010, where it continues its spread (Bakonyi et al., 2006; Papa et al., 2011; Wodak et al., 2011). Almost simultaneously, in Russia (Volga basin) a new epidemic caused by a lineage $2 \mathrm{WNV}$ which is genetically different from the variant affecting central Europe, was observed, causing an increasing number of human cases since 2004 to date (Platonov et al., 2008). This virus has extended westward reaching Romania in 2010 (Sirbu et al., 2011).

This new wave of WNV in Europe differed from the former in several aspects. Firstly, its duration: this wave has extended further in time, to the point that it is still ongoing with increasing intensity, Since the late 1990s sporadic outbreaks have occurred in the same locations in consecutive years. For example, in the Camargue, France, after the first outbreak of 2000, new outbreaks occurred in 2003, 2004, and 2006 (Zientara et al., 2009), and virus isolates available from these outbreaks were very closely related phylogenetically (Sotelo et al., 2011b). This fact supports that the virus is circulating endemically in the area since 2000 or before. In Morocco, an outbreak occurred in 2003 affecting horses, similar to that produced in 1996, and again, WNV isolates from both outbreaks show a striking similarity at the genetic level (Sotelo et al., 2011b). In Italy an outbreak occurred in horses in Tuscany in 1998, and 10 years later, in 2008, a serious epidemic took place in the Po river delta, which affected hundreds of horses and produced some human cases. Since then the same area has been affected by epidemic waves of WNF every year to date, and again, the viruses isolated in consecutive years are genetically closely related (Sotelo et al., 2011b). In Spain the first WNV isolation took place in 2007 from golden eagles (Jimenez-Clavero et al., 2008). Later, an outbreak affecting horses and humans occurred in 2010, which continued in 2011 (OIE, 2010). Apparently, all the viruses isolated since 1996 from western Mediterranean countries (France, Italy, Morocco, Portugal, and Spain), have a close phylogenetic relationship, which, as noted above, supports a single introduction in the area of a virus which has been able to remain endemic and spread in the area during all these years (Sotelo et al., 2011b). Secondly, the affected territory is more extended in the present epidemic wave than in the previous one. In fact there are more countries affected than ever in Europe. Moreover, the number of clinical cases is higher (Sotelo et al., 2011a). Exceptionally severe, with unusually high mortality in humans, were the epidemics on an "urban cycle" that occurred in 1996 in Bucharest, Romania (about 1,000 human cases, 396 severe, 17 deaths), in 1999 in Volgograd, Russia (approximately 1,000 human cases, 40 deaths), in 1998-1999 in Israel (about 400 human cases, 35 deaths) and in Greece in 2010-2011 (336 human cases, 40 deaths;
Anonymous, 2011). Finally, the range of WNV variants circulating in Europe is presumably higher than in the previous wave: While all isolates analyzed from European outbreaks occurring between 1951 and 1971 belonged to lineage 1, more recent European outbreaks have revealed not only two "classic" WNV lineages (1 and 2), but also up to three "unusual" WNV variants, including Rabensburg strain or lineage 3, Krasnodar strain or lineage 4 and putative lineage 7 from Spain.

However, the most striking change in WNV epidemiology occurred when the virus reached the American continent in 1999. This year the virus appeared in New York in an unexpected and not yet well explained way. This event initiated the largest WNV epidemic in history. The virus spread relentlessly throughout the continent, reaching the Pacific coast and Canada in 2002. Only in the U.S. the virus has caused to date about 30,000 clinical cases in humans of which more than 1,000 were fatal. The disease incidence peaked in 2004 and since then a slow decline in clinical cases has been observed (reviewed in Murray et al., 2010). WNV is now considered endemic in North America, after continuous circulation for 12 consecutive seasons and in its southward advance has produced sporadic disease cases in Central America and the Caribbean. In South America the virus has remained essentially unnoticed, except for an outbreak in horses in Argentina in 2006 (Morales et al., 2006). The reason why WNV circulates with such great intensity in North America, compared with other regions of the world, currently has no explanation.

\section{WEST NILE FEVER/ENCEPHALITIS: FUTURE TRENDS}

The past 15 years have witnessed an unprecedented expansion of a disease caused by an arbovirus, WNV, shared by animals and man. This expansion has taken place in parallel with an increased incidence of the disease in susceptible hosts, mostly birds, horses, and humans (Brault, 2009). While in the Old World warning signs were observed at the end of the last decade of the twentieth century, the emergence of WNV in the New World triggered all alarms. There the virus found a vast territory plenty of new naïve hosts, and initiated one of the major arbovirus epidemics known so far. WNV arrived in America to stay, as evidenced by the fact that the numbers of human cases diagnosed in the last years have stabilized at around 1,000 per year (CDC, 2011).

With regard to the relationship between climate change and the observed expansion and increase in cases of WNF some climatic patterns influencing local WNV circulation can be pointed out. Firstly, high temperatures enhance virogenesis in vectors (Reisen et al., 2006), which, along with vector abundance and competence, promote the occurrence of WNV outbreaks. Therefore, abnormally dry and hot summers, accompanied by mild winters, favor WNV circulation, while extremely cold winters break WNV cycle and disrupt its transmission, as illustrated in the following example: in southern Russia (Volgograd region) after several seasons (1997-2002) with extremely hot summers followed by mild winters, the circulation of WNV was enhanced, but two upcoming harsh winters disrupted this circulation and caused that lineage $1 \mathrm{WNV}$, responsible of the outbreaks thus far, ceased its activity and extinguished, Two years later (2004), once more favorable climatic conditions were restored, WNV re-emerged and caused new clinical cases in humans, but, as mentioned above, this time 
the virus circulating did not belong to the classic lineage 1, but to a newly introduced variant, which was identified as lineage 2 (Platonov et al., 2008). This example illustrates quite well how WNV epidemiology is determined by climatic factors, and yearto-year variations can lead to $\mathrm{WNV}$ enhancement or extinction from an endemic area. Other well-known episodes of WNF epidemics occurred in scenarios of abnormally hot summers, such as in Israel in 1998 (Paz, 2006) or New York in 1999 (Epstein, 2001). Secondly, it is known that a prolonged drought after a heavy rainy season promotes the habitat of Culex vectors by enhancing accumulation of organic matter in suspension in standing water. Severe drought episodes preceding by few months the onset of WNF outbreaks have been documented in the United States (Shaman et al., 2005). Thirdly, episodes of heavy rains, hurricanes, floods, and overflow of river basins have been implicated in the onset, or increase in outbreaks, of WNF. The WNV outbreak that occurred in the Czech Republic in 1997 was preceded by significant flooding, including severe flooding of the river Vltava in central Bohemia. In another instance, a few weeks after Hurricane Katrina affected Louisiana and Mississippi a significant increase of cases of WNV neuroinvasive disease was observed in the area (Caillouet et al., 2008).

Significantly, all weather conditions favoring the occurrence of WNF outbreaks, mentioned above, such as extremely hot summers, mild winters, droughts, floods, hurricanes, etc., tend to increase in frequency and intensity according to predictions on climate changes described in Section "Climate Change and Emerging Infectious Diseases" and listed in Table 2. However, current

\section{REFERENCES}

Abbassy, M. M., Osman, M., and Marzouk, A. S. (1993). West Nile virus (Flaviviridae: Flavivirus) in experimentally infected Argas ticks (Acari: Argasidae). Am. J. Trop. Med. Hyg. 48, 726-737.

Afshar, A., Eaton, B. T., Wright, P. F., Pearson, J. E., Anderson, J., Jeggo, M., and Trotter, H. C. (1992). Competitive ELISA for serodiagnosis of bluetongue: evaluation of groupspecific monoclonal antibodies and expressed VP7 antigen. J. Vet. Diagn. Invest. 4, 231-237.

Alexander, D. J. (2000). A review of avian influenza in different bird species. Vet. Microbiol. 74, 3-13.

Alter, M. J. (2002). Prevention of spread of hepatitis C. Hepatology 36, S93-S98.

Anonymous. (2011). Review of the Epidemiological Situation of West Nile Virus Infection in the European Union, 19 September 2011 (ECDC:Ed). Available at: http://ecdc.europa.eu/ en/publications/Publications/110920 _TER_Rapid\%20risk\%20assessment _WNF.pdf (accessed April 24, 2012).

Austgen, L. E., Bowen, R. A., Bunning, M. L., Davis, B. S., Mitchell, C. J., and Chang, G. J. (2004). Experimental infection of cats and dogs with
West Nile virus. Emerg. Infect. Dis. 10, 82-86.

Bagnarelli, P., Marinelli, K., Trotta, D., Monachetti, A., Tavio, M., Del Gobbo, R., Capobianchi, M., Menzo, S., Nicoletti, L., Magurano, F., and Varaldo, P. (2011). Human case of autochthonous West Nile virus lineage 2 infection in Italy, September 2011. Euro Surveill. 16, pii: 20002.

Bakonyi, T., Hubalek, Z., Rudolf, I., and Nowotny, N. (2005). Novel flavivirus or new lineage of West Nile virus, central Europe. Emerg. Infect. Dis. 11, 225-231.

Bakonyi, T., Ivanics, E., Erdelyi, K., Ursu, K., Ferenczi, E., Weissenbock, H., and Nowotny, N. (2006). Lineage 1 and 2 strains of encephalitic West Nile virus, central Europe. Emerg. Infect. Dis. 12, 618-623.

Banet-Noach, C., Simanov, L., and Malkinson, M. (2003). Direct (nonvector) transmission of West Nile virus in geese. Avian Pathol. 32, 489-494.

Batten, C. A., Harif, B., Henstock, M. R., Ghizlane, S., Edwards, L., Loutfi, C., Oura, C. A., and El Harrak, M. (2011). Experimental infection of camels with bluetongue virus. Res. Vet. Sci. 90, 533-535.
WNV emergence cannot be easily explained by a single factor such as climate change, but, more likely, a number of factors, both abiotic and biotic, might contribute. Among these factors, the emergence of new virus phenotypes, more virulent and/or more transmissible and/or more adapted to their hosts and/or vectors, could play an important role (Brault, 2009). Also, other factors related to globalization mentioned above, such as increase of transport, animal movements, etc., are likely to be involved in the observed geographical expansion of WNV. Taking these factors into account, and the observed climate trends mentioned above, WNF will only be expected to move forward in the twenty-first century.

\section{CONCLUSION}

Certain arboviral animal diseases such as BT and WNF have undergone significant changes in their known epidemiology, gaining unprecedented importance in the past 15 years. It is plausible that this increase has been influenced by climate changes, although their importance relative to other environmental factors (changes in agriculture, land uses, etc.) is difficult to estimate. Predictive models on climate in the coming years foresee an intensification of the circumstances favoring the activity of these arboviral pathogens. BT and WNF constitute paradigms of emerging infectious diseases whose fate is linked to global changes.

\section{ACKNOWLEDGEMENT}

This work was funded by EU grant HEALTH.2010.2.3.3-3 Project 261391 EuroWestNile.

Beaty, B. J., Calisher, C., and Shope, R. (1989). "Arboviruses," in Diagnostic Procedures for Viral, Rickettsial and Chlamydial Infections, eds N. J. Schmidt and R. W. Emmons (Washington, DC: American Public Health Association), 797-855.

Blackburn, N. K., Reyers, F., Berry, W. L., and Shepherd, A. J. (1989). Susceptibility of dogs to West Nile virus: a survey and pathogenicity trial. $J$. Comp. Pathol. 100, 59-66.

Blitvich, B. J. (2008). Transmission dynamics and changing epidemiology of West Nile virus. Anim. Health Res. Rev. 9, 71-86.

Bondre, V. P., Jadi, R. S., Mishra, A. C., Yergolkar, P. N., and Arankalle, V. A (2007). West Nile virus isolates from India: evidence for a distinct genetic lineage. J. Gen. Virol. 88, 875-884.

Bonneau, K. R., DeMaula, C. D., Mullens, B. A., and MacLachlan, N. J. (2002). Duration of viraemia infectious to Culicoides sonorensis in bluetongue virus-infected cattle and sheep. Vet. Microbiol. 88, 115-125.

Brault, A. C. (2009). Changing patterns of West Nile virus transmission: altered vector competence and host susceptibility. Vet. Res. 40, 43.

Brown, C. (2004). Emerging zoonoses and pathogens of public health significance - an overview. Rev. Sci. Tech. 23, 435-442.

Caillouet, K. A., Michaels, S. R., Xiong, X., Foppa, I., and Wesson, D. M. (2008). Increase in West Nile neuroinvasive disease after Hurricane Katrina. Emerg. Infect. Dis. 14 804-807.

Calistri, P., Giovannini, A., Hubalek, Z., Ionescu, A., Monaco, F., Savini, G., and Lelli, R. (2010). Epidemiology of West Nile in Europe and in the Mediterranean basin. Open Virol. J. 4, 29.

Carpenter, S., Wilson, A., and Mellor, P. S. (2009). Culicoides and the emergence of bluetongue virus in northern Europe. Trends Microbiol. 17, 172-178.

Castillo-Olivares, J., and Wood, J. (2004). West Nile virus infection of horses. Vet. Res. 35, 467-483.

CDC. (2011). West Nile Virus-Statistics, Surveillance, and Control. Atlanta, GA: Centers for Diseases Control and Prevention.

Charrel, R. N., Brault, A. C., Gallian, P., Lemasson, J. J., Murgue, B., Murri, S., Pastorino, B., Zeller, H., de Chesse, R., de Micco, P., and de, L. X. (2003). Evolutionary relaNile virus strains. Evidence for viral tionship between Old World West 
gene flow between Africa, the Middle East, and Europe. Virology 315, 381-388.

Charrel, R. N., and de Lamballerie, X. (2003). Arenaviruses other than Lassa virus. Antiviral Res. 57, 89-100.

Christensen, J. H. (2005). Prediction of Regional Scenarios and Uncertainties for Defining European Climate Change Risks and Effects. PRUDENCE EVK2-CT2001-00132 Final Report. Available at: http://prudence.dmi.dk/ (accessed April 15, 2012).

Conte, A., Gilbert, M., and Goffredo, M. (2009). Eight years of entomological surveillance in Italy show no evidence of Culicoides imicola geographical range expansion. J. Appl. Ecol. 46, 1332-1339.

Cui, J., Han, N., Streicker, D., Li, G., Tang, X., Shi, Z., Hu, Z., Zhao, G., Fontanet, A., Guan, Y., Wang, L. Jones, G., Field, H. E., Daszak, P., and Zhang, S. (2007). Evolutionary relationships between bat coronaviruses and their hosts. Emerg. Infect. Dis. 13, 1526-1532.

Darpel, K. E., Batten, C. A., Veronesi, E., Shaw, A. E., Anthony, S., BachanekBankowska, K., Kgosana, L., BinTarif, A., Carpenter, S., MüllerDoblies, U. U., Takamatsu, H. H., Mellor, P. S., Mertens, P. P., and Oura, C. A. (2007). Clinical signs and pathology shown by British sheep and cattle infected with bluetongue virus serotype 8 derived from the 2006 outbreak in northern Europe. Vet. Rec. 161, 253-261.

Dawson, J. R., Stone, W. B., Ebel, G. D., Young, D. S., Galinski, D. S., Pensabene, J. P., Franke, M. A., Eidson, M., and Kramer, L. D. (2007). Crow deaths caused by West Nile virus during winter. Emerg. Infect. Dis. 13, 1912-1914.

De Filette, M., Ulbert, S., Diamond, M., and Sanders, N. N. (2012). Recent progress in West Nile virus diagnosis and vaccination. Vet. Res. 43, 16.

DeMaula, C. D., Heidner, H. W., Rossitto, P. V., Pierce, C. M., and MacLachlan, N. J. (1993). Neutralization determinants of United States bluetongue virus serotype ten. Virology 195, 292-296.

Drosten, C., Gunther, S., Preiser, W., van der Werf, S., Brodt, H. R., Becker, S., Rabenau, H., Panning, M., Kolesnikova, L., Fouchier, R. A., Berger, A., Burguiere, A. M., Cinatl, J., Eickmann, M., Escriou, N., Grywna, K., Kramme, S., Manuguerra, J. C., Muller, S., Rickerts, V., Sturmer, M., Vieth, S., Klenk, H. D., Osterhaus, A. D., Schmitz, H., and Doerr, H.W. (2003). Identification of a novel coronavirus in patients with severe acute respiratory syndrome. N. Engl. J. Med. 348, 1967-1976.

Duarte, C. (2006). Cambio global: Impacto de la actividad humana sobre el planeta tierra. Madrid: CSIC.

Ducheyne, E., De Deken, R., Becu, S., Codina, B., Nomikou, K., ManganaVougiaki, O., Georgiev, G., Purse, B. V., and Hendickx, G. (2007). Quantifying the wind dispersal of Culicoides species in Greece and Bulgaria. Geospat. Health 1, 177-189.

Eaton, B. T., Broder, C. C., Middleton, D., and Wang, L. F. (2006). Hendra and Nipah viruses: different and dangerous. Nat. Rev. Microbiol. 4, 23-35.

EEA. (2012). Mean Surface Temperature in Europe 1850-2009, Annual and by Season. Copenhagen: European Environmental Agency. Available at: http://www.eea.europa.eu/dataand-maps/figures/mean-surfacetemperature-in-europe.

El-Harrak, M., Martin-Folgar, R., Llorente, F., Fernandez-Pacheco, P., Brun, A., Figuerola, J., and JimenezClavero, M. A. (2011). Rift Valley and West Nile virus antibodies in camels, north Africa. Emerg. Infect. Dis. 17, 2372-2374.

Epstein, P. R. (2001). West Nile virus and the climate. J. Urban Health 78, 367-371.

Escribano-Romero, E., JimenezClavero, M. A., and Ley, V. (2000). Swine vesicular disease virus. Pathology of the disease and molecular characteristics of the virion. Anim. Health Res. Rev. 1, 119-126.

EUBTNET. (2011). Bluetongue Epidemiological Situation in EU Member States and Third Countries. Available at: http://eubtnet.izs.it/btnet/ reports/EpidemiologicalSituation. html (accessed April 23, 2012).

Falconi, C., Lopez-Olvera, J. R., and Gortazar, C. (2011). BTV infection in wild ruminants, with emphasis on red deer: a review. Vet. Microbiol. 151, 209-219.

Fayer, R. (2000). Presidential address. Global change and emerging infectious diseases. J. Parasitol. 86, 1174-1181.

Fernandez-Pacheco, P., FernandezPinero, J., Aguero, M., and JimenezClavero, M. A. (2008). Bluetongue virus serotype 1 in wild mouflons in Spain. Vet. Rec. 162, 659-660.

Formosinho, P., and Santos-Silva, M. M. (2006). Experimental infection of Hyalomma marginatum ticks with West Nile virus. Acta Virol. 50, 175-180.

Garmendia, A. E., Van Kruiningen, H. J., French, R. A., Anderson, J. F., Andreadis, T. G., Kumar, A., and
West, A. B. (2000). Recovery and identification of West Nile virus from a hawk in winter. J. Clin. Microbiol. 38, 3110-3111.

Goldarazena, A., Romon, P., Aduriz, G., Balenghien, T., Baldet, T., and Delecolle, J. C. (2008). First record of Culicoides imicola, the main vector of bluetongue virus in Europe, in the Basque Country (northern Spain). Vet. Rec. 162, 820-821.

Gould, E. A., and Higgs, S. (2009). Impact of climate change and other factors on emerging arbovirus diseases. Trans. R. Soc. Trop. Med. Hyg. 103, 109-121.

Guarner, J., Johnson, B. J., Paddock, C. D., Shieh, W. J., Goldsmith, C. S., Reynolds, M. G., Damon, I. K., Regnery, R. L., and Zaki, S. R. (2004). Monkeypox transmission and pathogenesis in prairie dogs. Emerg. Infect. Dis. 10, 426-431.

Gurley, E. S., Montgomery, J. M., Hossain, M. J., Bell, M., Azad, A. K., Islam, M. R., Molla, M. A. R., Carroll, D. S., Ksiazek, T. G., Rota, P. A., Lowe, L., Comer, J. A., Rollin, P., Czub, M., Grolla, A., Feldmann, H., Luby, S. P., Woodward, J. L., and Breiman, R. F. (2007). Person-to-Person Transmission of Nipah Virus in a Bangladeshi Community. Emerg. Infect. Dis. 13, 1031-1037.

Hayes, E. B., Komar, N., Nasci, R. S., Montgomery, S. P., O'Leary, D. R., and Campbell, G. L. (2005a). Epidemiology and transmission dynamics of West Nile virus disease. Emerg. Infect. Dis. 11, 1167-1173.

Hayes, E. B., Sejvar, J. J., Zaki, S. R., Lanciotti, R. S., Bode, A. V., and Campbell, G. L. (2005b). Virology, pathology, and clinical manifestations of West Nile virus disease. Emerg. Infect. Dis. 11, 1174-1179.

Hofmann, M. A., Renzullo, S., Mader, M., Chaignat, V., Worwa, G., and Thuer, B. (2008). Genetic characterization of toggenburg orbivirus, a new bluetongue virus, from goats, Switzerland. Emerg. Infect. Dis. 14, 1855-1861.

Hubalek, Z., and Halouzka, J. (1999). West Nile fever - a reemerging mosquito-borne viral disease in Europe. Emerg. Infect. Dis. 5, 643-650.

Hutcheson, H. J., Gorham, C. H., Machain-Williams, C., Lorono-Pino, M. A., James, A. M., Marlenee, N. L., Winn, B., Beaty, B. J., and Blair, C. D. (2005). Experimental transmission of West Nile virus (Flaviviridae: Flavivirus) by Carios capensis ticks from North America. Vector Borne Zoonotic Dis. 5, 293-295.
Imai, M., and Kawaoka, Y. (2012). The role of receptor binding specificity in interspecies transmission of influenza viruses. Curr. Opin. Virol. 2, 160-167.

IPPC. (2001). Third Assessment Report. Cambridge: IPPC.

IPPC. (2007). Fourth Assessment Report. Cambridge: IPPC.

Jimenez-Clavero, M. A., Aguero, M., San Miguel, E., Mayoral, T., Lopez, M. C., Ruano, M. J., Romero, E., Monaco, F., Polci, A., Savini, G., and GomezTejedor, C. (2006). High throughput detection of bluetongue virus by a new real-time fluorogenic reverse transcription-polymerase chain reaction: application on clinical samples from current Mediterranean outbreaks. J. Vet. Diagn. Invest. 18 , 7-17.

Jimenez-Clavero, M. A., EscribanoRomero, E., Ley, V., and Spiller, O. B. (2005a). More recent swine vesicular disease virus isolates retain binding to coxsackie-adenovirus receptor, but have lost the ability to bind human decay-accelerating factor (CD55). J. Gen. Virol. 86, 1369-1377.

Jimenez-Clavero, M. A., Ley, V., Gomez, N., and Sáiz, J. C. (2005b). "Detection of enteroviruses," in Food Borne Pathogens: Methods and Protocols, ed. C. Adley (Totowa: Humana Press), 53-169.

Jimenez-Clavero, M. A., Sotelo, E., Fernandez-Pinero, J., Llorente, F., Blanco, J. M., Rodriguez-Ramos, J., Perez-Ramirez, E., and Hofle, U. (2008). West Nile virus in golden eagles, Spain, 2007. Emerg. Infect. Dis. 14, 1489-1491.

Jourdain, E., Gauthier-Clerc, M., Bicout, D. J., and Sabatier, P. (2007). Bird migration routes and risk for pathogen dispersion into western Mediterranean wetlands. Emerg. Infect. Dis. 13, 365-372.

Karoly, D. J., Braganza, K., Stott, P. A., Arblaster, J. M., Meehl, G. A., Broccoli, A. J., and Dixon, K. W. (2003). Detection of a human influence on North American climate. Science 302 , 1200-1203.

Komar, N., Langevin, S., Hinten, S., Nemeth, N., Edwards, E., Hettler, D., Davis, B., Bowen, R., and Bunning, M. (2003). Experimental infection of North American birds with the New York 1999 strain of West Nile virus. Emerg. Infect. Dis. 9, 311-322.

Kostiukov, M. A., Alekseev, A. N., Bulychev, V. P., and Gordeeva, Z. E. (1986). Experimental evidence for infection of Culex pipiens L. mosquitoes by West Nile fever virus from Rana ridibunda Pallas and its 
transmission by bites. Med. Parazitol. (Mosk), 76-78.

Kramer, L. D., Styer, L. M., and Ebel, G. D. (2008). A global perspective on the epidemiology of West Nile virus. Annu. Rev. Entomol. 53, 61-81.

Kuiken, T., Fouchier, R. A., Schutten, M., Rimmelzwaan, G. F., van Amerongen, G., van Riel, D., Laman, J. D., de Jong, T., van Doornum, G., Lim, W., Ling, A. E., Chan, P. K., Tam, J. S., Zambon, M. C., Gopal, R., Drosten, C., van der Werf, S., Escriou, N., Manuguerra, J. C., Stohr, K., Peiris, J. S., and Osterhaus, A. D. (2003). Newly discovered coronavirus as the primary cause of severe acute respiratory syndrome. Lancet 362, 263-270.

Lederberg, J. (1997). Infectious disease as an evolutionary paradigm. Emerg. Infect. Dis. 3, 417-423.

Li, W., Shi, Z., Yu, M., Ren, W., Smith, C., Epstein, J. H., Wang, H., Crameri, G., Hu, Z., Zhang, H., Zhang, J., McEachern, J., Field, H., Daszak, P., Eaton, B. T., Zhang, S., and Wang, L. F. (2005). Bats are natural reservoirs of SARS-like coronaviruses. Science 310, 676-679.

Lopez-Olvera, J. R., Falconi, C., Fernandez-Pacheco, P., FernandezPinero, J., Sanchez, M. A., Palma, A., Herruzo, I., Vicente, J., JimenezClavero, M. A., Arias, M., SanchezVizcaino, J. M., and Gortazar, C. (2010). Experimental infection of European red deer (Cervus elaphus) with bluetongue virus serotypes 1 and 8. Vet. Microbiol. 145, 148-152.

Lvov, D. K., Butenko, A. M., Gromashevsky, V. L., Kovtunov, A. I., Prilipov, A. G., Kinney, R., Aristova, V. A., Dzharkenov, A. F., Samokhvalov, E. I., Savage, H. M., Shchelkanov, M. Y., Galkina, I. V., Deryabin, P. G., Gubler, D. J., Kulikova, L. N., Alkhovsky, S. K., Moskvina, T. M., Zlobina, L. V., Sadykova, G. K., Shatalov, A. G., Lvov, D. N., Usachev, V. E., and Voronina, A. G. (2004). West Nile virus and other zoonotic viruses in Russia: examples of emergingreemerging situations. Arch. Virol. Suppl. 18, 85-96.

Maan, S., Maan, N. S., Nomikou, K., Batten, C., Antony, F., Belaganahalli, M. N., Samy, A. M., Reda, A. A., AlRashid, S. A., El Batel, M., Oura, C. A., and Mertens, P. P. (2011). Novel bluetongue virus serotype from Kuwait. Emerg. Infect. Dis. 17, 886-889.

Maan, S., Maan, N. S., Ross-smith, N., Batten, C. A., Shaw, A. E., Anthony, S. J., Samuel, A. R., Darpel, K. E., Veronesi, E., Oura, C. A., Singh, K. P., Nomikou, K., Potgieter, A. C., Attoui, H., van Rooij, E., van Rijn, P., De
Clercq, K., Vandenbussche, F., Zientara, S., Breard, E., Sailleau, C., Beer, M., Hoffman, B., Mellor, P. S., and Mertens, P. P. (2008). Sequence analysis of bluetongue virus serotype 8 from the Netherlands 2006 and comparison to other European strains. Virology 377, 308-318.

Mackenzie, J. S., Gubler, D. J., and Petersen, L. R. (2004). Emerging flaviviruses: the spread and resurgence of Japanese encephalitis, West Nile and dengue viruses. Nat. Med. 10, S98-S109.

MacLachlan, N. J. (1994). The pathogenesis and immunology of bluetongue virus infection of ruminants. Comp. Immunol. Microbiol. Infect. Dis. 17, 197-206.

MacLachlan, N. J. (2004). Bluetongue: pathogenesis and duration of viraemia. Vet. Ital. 40, 462-467.

MacLachlan, N. J. (2011). Bluetongue: history, global epidemiology, and pathogenesis. Prev. Vet. Med. 102, 107-111.

MacLachlan, N. J., Drew, C. P., Darpel, K. E., and Worwa, G. (2009). The pathology and pathogenesis of bluetongue. J. Comp. Pathol. 141, 1-16.

MacLachlan, N. J., and Guthrie, A. J. (2010). Re-emergence of bluetongue, African horse sickness, and other orbivirus diseases. Vet. Res. 41, 35.

MacLachlan, N. J., Nunamaker, R. A., Katz, J. B., Sawyer, M. M., Akita, G. Y., Osburn, B. I., and Tabachnick, W. J. (1994). Detection of bluetongue virus in the blood of inoculated calves: comparison of virus isolation, PCR assay, and in vitro feeding of Culicoides variipennis. Arch. Virol. 136, 1-8.

Madon, M. B., Mulla, M. S., Shaw, M. W., Kluh, S., and Hazelrigg, J. E. (2002). Introduction of Aedes albopictus (Skuse) in southern California and potential for its establishment. J. Vector Ecol. 27, 149-154.

Makoschey, B., van Gelder, P. T., Keijsers, V., and Goovaerts, D. (2003). Bovine viral diarrhoea virus antigen in foetal calf serum batches and consequences of such contamination for vaccine production. Biologicals 31, 203-208.

Malkinson, M., Banet, C., Weisman, Y., Pokamunski, S., King, R., Drouet, M. T., and Deubel, V. (2002). Introduction of West Nile virus in the Middle East by migrating white storks. Emerg. Infect. Dis. 8, 392-397.

Martin, V., Chevalier, V., Ceccato, P., Anyamba, A., De Simone, L., Lubroth, J., de La Rocque, S., and Domenech, J. (2008). The impact of climate change on the epidemiology and control of Rift Valley fever. Rev. Sci. Tech. 27, 413-426.

McLean, R. G., Ubico, S. R., Bourne, D., and Komar, N. (2002). West Nile virus in livestock and wildlife. Curr. Top. Microbiol. Immunol. 267, 271-308.

Meadows, D. H., Meadows, D. L., Randers, J., and Behrens, W. W. III (1972). The Limits to Growth. A Report for the Club of Rome's Project on the Predicament of Mankind. New York: Universe Books.

Mecham, J. O., and Wilson, W. C. (2004). Antigen capture competitive enzyme-linked immunosorben assays using baculovirus-expressed antigens for diagnosis of bluetongue virus and epizootic hemorrhagic disease virus. J. Clin. Microbiol. 42, 518-523.

Mellor, P. S., Carpenter, S., Harrup, L., Baylis, M., and Mertens, P. P. (2008). Bluetongue in Europe and the Mediterranean Basin: history of occurrence prior to 2006. Prev. Vet. Med. 87, 4-20.

Mellor, P. S., and Wittmann, E. J. (2002) Bluetongue virus in the Mediterranean Basin 1998-2001. Vet. J. 164, 20-37.

Miller, D. L., Mauel, M. J., Baldwin, C., Burtle, G., Ingram, D., Hines, M. E. II, and Frazier, K. S. (2003). West Nile virus in farmed alligators. Emerg. Infect. Dis. 9, 794-799.

Mintiens, K., Meroc, E., Mellor, P. S., Staubach, C., Gerbier, G., Elbers, A. R., Hendrickx, G., and De Clercq, K. (2008). Possible routes of introduction of bluetongue virus serotype 8 into the epicentre of the 2006 epidemic in north-western Europe. Prev. Vet. Med. 87, 131-144.

Mishra, A. C., and Mourya, D. T. (2001). Transovarial transmission of West Nile virus in Culex vishnui mosquito. Indian J. Med. Res. 114, 212-214.

Morales, M. A., Barrandeguy, M., Fabbri, C., Garcia, J. B., Vissani, A., Trono, K., Gutierrez, G., Pigretti, S., Menchaca, H., Garrido, N., Taylor, N., Fernandez, F., Levis, S., and Enria, D. (2006). West Nile virus isolation from equines in Argentina, 2006. Emerg. Infect. Dis. 12 1559-1561.

Murgue, B., Murri, S., Triki, H., Deubel, V., and Zeller, H. G. (2001). West Nile in the Mediterranean basin: 19502000. Ann. N. Y. Acad. Sci. 951, 117-126.

Murray, K. O., Mertens, E., and Despres, P. (2010). West Nile virus and its emergence in the United States of America. Vet. Res. 41, 67.
OIE. (2008). Manual of Diagnostic Tests and Vaccines for Terrestrial Animals. Paris: Office International des Epizooties.

OIE. (2010). West Nile Fever, Spain (Immediate notification: 10/09/2010). Paris: World Organisation for Animal Health.

OIE. (2011). Terrestrial Animal Health Code. Paris: OIE World Organisation for Animal Health.

Oreskes, N. (2004). Beyond the ivory tower. The scientific consensus on climate change. Science 306, 1686.

Papa, A., Bakonyi, T., Xanthopoulou, K., Vazquez, A., Tenorio, A., and Nowotny, N. (2011). Genetic characterization of West Nile virus lineage 2, Greece, 2010. Emerg. Infect. Dis. 17, 920-922.

Parkman, P. D. (1996). Safety of biopharmaceuticals: a current perspective. Dev. Biol. Stand. 88, 5-7.

Patz, J. A., Olson, S. H., Uejio, C. K., and Gibbs, H. K. (2008). Disease emergence from global climate and land use change. Med. Clin. North Am. 92 , 1473-1491.

Paupy, C., Delatte, H., Bagny, L., Corbel, V., and Fontenille, D. (2009). Aedes albopictus, an arbovirus vector: from the darkness to the light. Microbes Infect. 11, 1177-1185.

Paz, S. (2006). The West Nile Virus outbreak in Israel (2000) from a new perspective: the regional impact of climate change. Int. J. Environ. Health Res. 16, 1-13.

Pellet, P. E., and Roizman, B. (2007). "The family herpesviridae: a brief introduction," in Fields Virology, eds D. M. Knipe and P. M. Howley (Philadelphia: Lippincott Williams \& Wilkins), 2479-2499.

Pierce, C. M., Rossitto, P. V., and MacLachlan, N. J. (1995). Homotypic and heterotypic neutralization determinants of bluetongue virus serotype 17. Virology 209, 263-267.

Platonov, A. E., Fedorova, M. V., Karan, L. S., Shopenskaya, T. A., Platonova, O. V., and Zhuravlev, V. I. (2008). Epidemiology of West Nile infection in Volgograd, Russia, in relation to climate change and mosquito (Diptera: Culicidae) bionomics. Parasitol. Res. 103(Suppl. 1), S45-S53.

Prati, D. (2006). Transmission of hepatitis $\mathrm{C}$ virus by blood transfusions and other medical procedures: a global review. J. Hepatol. 45, 607-616. Purse, B. V., Brown, H. E., Harrup, L., Mertens, P. P., and Rogers, D. J. (2008). Invasion of bluetongue and other orbivirus infections into Europe: the role of biological and climatic processes. Rev. Sci. Tech. 27, 427-442. 
Randolph, S. E., and Rogers, D. J. (2010). The arrival, establishment and spread of exotic diseases: patterns and predictions. Nat. Rev. Microbiol. 8, 361-371.

Reisen, W. K., Fang, Y., and Martinez, V. M. (2006). Effects of temperature on the transmission of west nile virus by Culex tarsalis (Diptera: Culicidae). J. Med. Entomol. 43, 309-317.

Reiter, P., and Sprenger, D. (1987). The used tire trade: a mechanism for the worldwide dispersal of container breeding mosquitoes. J. Am. Mosq. Control Assoc. 3, 494-501.

Rodhain, F., Petter, J. J., Albignac, R., Coulanges, P., and Hannoun, C. (1985). Arboviruses and lemurs in Madagascar: experimental infection of Lemur fulvus with yellow fever and West Nile viruses. Am. J. Trop. Med. Hyg. 34, 816-822.

Root, J. J., Oesterle, P. T., Nemeth, N. M., Klenk, K., Gould, D. H., McLean, R. G., Clark, L., and Hall, J. S. (2006). Experimental infection of fox squirrels (Sciurus niger) with West Nile virus. Am. J. Trop. Med. Hyg. 75, 697-701.

Rosenthal, J. (2009). Climate change and the geographic distribution of infectious diseases. Ecohealth 6, 489-495.

Saegerman, C., Berkvens, D., and Mellor, P. S. (2008). Bluetongue epidemiology in the European Union. Emerg. Infect. Dis. 14, 539-544.

Scherret, J. H., Poidinger, M., Mackenzie, J. S., Broom, A. K., Deubel, V., Lipkin, W. I., Briese, T., Gould, E. A., and Hall, R. A. (2001). The relationships between West Nile and Kunjin viruses. Emerg. Infect. Dis. 7, 697-705.

Schulz, C., Eschbaumer, M., Rudolf, M., Konig, P., Keller, M., Bauer, C., Gauly, M., Grevelding, C. G., Beer, M., and Hoffmann, B. (2012). Experimental infection of South American camelids with bluetongue virus serotype 8. Vet. Microbiol. 154, 257-265.

Schwartz-Cornil, I., Mertens, P. P., Contreras, V., Hemati, B., Pascale, F., Breard, E., Mellor, P. S., MacLachlan, N. J., and Zientara, S. (2008). Bluetongue virus: virology, pathogenesis and immunity. Vet. Res. 39, 46.

Shaman, J., Day, J. F., and Stieglitz, M. (2005). Drought-induced amplification and epidemic transmission of West Nile virus in southern Florida. J. Med. Entomol. 42, 134-141.
Sirbu, A., Ceianu, C. S., PanculescuGatej, R. I., Vázquez, A., Tenorio, A. Rebreanu, R., Niedrig, M., Nicolescu, G., and Pistol, A. (2011). Outbreak of West Nile virus infection in humans, Romania, July to October 2010. Euro Surveill. 16, pii: 19762.

Smithburn, K. C., Hughs, T. P., Burke, A. W., and Paul, J. H. (1940). A neurotropic virus isolated from the blood of a native of Uganda. Am. J. Trop. Med. Hyg. 20, 471-492.

Smolinski, M. S., Hamburg, M. A., and Lederberg, J. (2003). Microbial Threats to Health: Emergence, Detection, and Response. Washington, DC: National Academy Press.

Sotelo, E., Fernandez-Pinero, J., and Jimenez-Clavero, M. A. (2011a). La fiebre/encefalitis por virus West Nile: reemergencia en Europa y situación en España. Enferm. Infecc. Microbiol. Clin. 30, 75-83.

Sotelo, E., Fernandez-Pinero, J., Llorente, F., Vazquez, A., Moreno, A., Aguero, M., Cordioli, P., Tenorio, A., and Jimenez-Clavero, M. A. (2011b). Phylogenetic relationships of western Mediterranean West Nile virus strains (1996-2010) using fulllength genome sequences: single or multiple introductions? J. Gen. Virol. 92, 2512-2522.

Sotelo, E., Llorente, F., Rebollo, B., Camunas, A., Venteo, A., Gallardo, C., Lubisi, A., Rodriguez, M. J., Sanz, A. J., Figuerola, J., and Jimenez-Clavero, M. A. (2011c). Development and evaluation of a new epitope-blocking ELISA for universal detection of antibodies to West Nile virus. J. Virol. Methods 174, 35-41.

Suarez, D. L. (2000). Evolution of avian influenza viruses. Vet. Microbiol. 74, 15-27.

Sutherst, R. W. (2004). Global change and human vulnerability to vectorborne diseases. Clin. Microbiol. Rev. 17, 136-173.

Tabachnick, W. J. (2010). Challenges in predicting climate and environmental effects on vector-borne disease episystems in a changing world. $J$. Exp. Biol. 213, 946-954.

Taylor, R. M., Work, T. H., Hurlbut, H. S., and Rizk, F. (1956). A study of the ecology of West Nile virus in Egypt. Am. J. Trop. Med. Hyg. 5, 579-620.

Teehee, M. L., Bunning, M. L., Stevens, S., and Bowen, R. A. (2005). Experimental infection of pigs with West
Nile virus. Arch. Virol. 150, 1249 1256.

Touil, N., Cherkaoui, Z., Lmrabih, Z., Loutfi, C., Harif, B., and El Harrak, M. (2012). Emerging viral diseases in dromedary camels in the Southern Morocco. Transbound. Emerg. Dis. $59,177-182$.

Trevejo, R. T., and Eidson, M. (2008). Zoonosis update: West Nile virus. J. Am. Vet. Med. Assoc. 232, 1302-1309.

Van Borm, S., Thomas, I., Hanquet, G., Lambrecht, B., Boschmans, M., Dupont, G., Decaestecker, M., Snacken, R., and van den Berg, T. (2005). Highly pathogenic H5N1 influenza virus in smuggled Thai eagles, Belgium. Emerg. Infect. Dis. 11, 702-705.

Vazquez, A., Sanchez-Seco, M. P., Ruiz, S., Molero, F., Hernandez, L., Moreno, J., Magallanes, A., Tejedor, C. G., and Tenorio, A. (2010). Putative new lineage of west nile virus, Spain. Emerg. Infect. Dis. 16, 549-552.

Venter, M., Steyl, J., Human, S., Weyer, J., Zaayman, D., Blumberg, L., Leman, P. A., Paweska, J., and Swanepoel, R. (2010). Transmission of West Nile virus during horse autopsy. Emerg. Infect. Dis. 16, 573-575.

Veronesi, E., Venter, G. J., Labuschagne, K., Mellor, P. S., and Carpenter, S. (2009). Life-history parameters of Culicoides (Avaritia) imicola Kieffer in the laboratory at different rearing temperatures. Vet. Parasitol. 163, 370-373.

Weaver, S. C., and Reisen, W. K. (2010). Present and future arboviral threats. Antiviral Res. 85, 328-345.

Weiss, R. A., and McMichael, A. J. (2004). Social and environmental risk factors in the emergence of infectious diseases. Nat. Med. 10, S70-S76.

Wilcox, B. A., and Gubler, D. J. (2005). Disease ecology and the global emergence of zoonotic pathogens. Environ. Health Prev. Med. 10 263-272.

Wilson, A., and Mellor, P. (2008). Bluetongue in Europe: vectors, epidemiology and climate change. Parasitol. Res. 103(Suppl. 1), S69-S77.

Wilson, A. J., and Mellor, P. S. (2009). Bluetongue in Europe: past, presen and future. Philos. Trans. R. Soc. Lond. B Biol. Sci. 364, 2669-2681.

Wilson, D. E., and Reeder, D. M. (2005). Mammal Species of the World: A
Taxonomic and Geographic Reference. Baltimore: Johns Hopkins University Press.

Wittmann, E. J., Mello, P. S., and Baylis, M. (2002). Effect of temperature on the transmission of orbiviruses by the biting midge, Culicoides sonorensis. Med. Vet. Entomol. 16, 147-156.

Wodak, E., Richter, S., Bago, Z., RevillaFernandez, S., Weissenbock, H., Nowotny, N., and Winter, P. (2011) Detection and molecular analysis of West Nile virus infections in birds of prey in the eastern part of Austria in 2008 and 2009. Vet. Microbiol. 149 358-366.

Woolhouse, M. E., and GowtageSequeria, S. (2005). Host range and emerging and reemerging pathogens. Emerg. Infect. Dis. 11, 1842-1847.

Zeller, H. G., and Schuffenecker, I. (2004). West Nile virus: an overview of its spread in Europe and the Mediterranean basin in contrast to its spread in the Americas. Eur. J. Clin. Microbiol. Infect. Dis. 23, 147-156.

Zientara, S., Lecollinet, S., Breard, E., Sailleau, C., and Boireau, P. (2009). La fièvre du Nil Occidental et la fièvre catarrhale ovine, deux viroses en progression inattendue. Bull. Acad. Vet. Fr. 162, 73-87.

Conflict of Interest Statement: The author declares that the research was conducted in the absence of any commercial or financial relationships that could be construed as a potential conflict of interest.

Received: 01 February 2012; accepted: 22 May 2012; published online: 13 June 2012.

Citation: Jiménez-Clavero MÁ (2012) Animal viral diseases and global change: bluetongue and West Nile fever as paradigms. Front. Gene. 3:105. doi 10.3389/fgene.2012.00105

This article was submitted to Frontiers in Systems Biology, a specialty of Frontiers in Genetics.

Copyright (๑) 2012 Jiménez-Clavero. This is an open-access article distributed under the terms of the Creative Commons Attribution Non Commercial License, which permits non-commercial use, distribution, and reproduction in other forums, provided the original authors and source are credited. 